\title{
Liability of Foreignness in Global Stock Markets: Liquidity Dynamics of Foreign IPOs in the US*
}

\author{
Chiara Banti \\ Essex Business School \\ University of Essex \\ cbanti@essex.ac.uk \\ Gary Biddle \\ Faculty of Business and Economics \\ University of Melbourne \\ gary.biddle@unimelb.edu.au \\ Igor Filatotchev \\ King's Business School \\ King's College London \\ igor.filatotchev@kcl.ac.uk \\ Jonathan Jona ${ }^{* *}$ \\ Faculty of Business and Economics \\ University of Melbourne \\ jonathan.jona@unimelb.edu.au
}

Draft: September 2017

JEL Classification: G01, M4, M49

Keywords: Foreign Listings, Initial Public Offerings, Liquidity, Liability of Foreignness

\footnotetext{
${ }^{*}$ We are grateful to Sonia Falconieri, Veliko Fotak, Matthew Leo Pinnuck, Marianna Russo, Naomi Soderstrom, and to participants in seminars at Australian National University, Brunel University, Central Bank of Chile, UniSinos, University of Bristol, University of Essex, University of Melbourne, University of Western Australia, University of Adelaide, the Auckland Finance Meeting, INFINITI Conference in Ljubljana, SFA Conference in Captiva Island, World Finance Conference in Buenos Aires, YSF Sussex Conference, and the 2016 JIBS conference for their helpful suggestions and comments.

** Corresponding author: Jonathan Jona, Department of Accounting, Faculty of Business and Economics, University of Melbourne, 198 Berkeley St. 3010 Melbourne, Australia, +61 (0) 38344 6799, http://fbe.unimelb.edu.au/accounting.
} 


\title{
Liability of Foreignness in Global Stock Markets: Liquidity Dynamics of Foreign IPOs in the US
}

\begin{abstract}
Using a unique dataset of foreign and domestic IPOs listings in the US from 1990 to 2012, we study how foreignness affects IPO liquidity. We find that foreign IPOs enjoy higher liquidity than IPOs in their home countries, but do not fully gain the same liquidity benefits as for IPOs of domestic US issuers. In contrast to prior evidence for mature cross-listed firms, we show that liquidity differentials between foreign and domestic IPOs in the US are determined by information asymmetry related to foreignness rather than to home-country institutional environment characteristics. Thus, our results extend prior findings to reveal salient differences in liquidity and liquidity determinants between IPOs offerings by foreign and domestic firms in the US.
\end{abstract}

Keywords: Foreign Listings, Initial Public Offerings, Liquidity, Liability of Foreignness 


\section{INTRODUCTION}

The effect of foreignness in the international business literature has traditionally been investigated in the context of globalized product markets (Zaheer, 1995; Mata and Freitas, 2012). This study contributes empirically to an emerging conceptual discussion regarding the effects of foreignness in international capital markets (e.g., Bell, Filatotchev and Rasheed, 2012; Filatotchev, Bell and Rasheed, 2016). Specifically, we examine whether firms that conduct initial public offerings (IPOs) abroad enjoy the same liquidity advantages as local host market firms, or rather suffer from a "liability of foreignness". ${ }^{1,2}$ A foreignness liquidity liability is salient for foreign IPOs, both because of their increasing numbers and because they differ in important regards from firms that cross-list with documented benefits for capital costs (Pagano, 1993; Pagano et al., 2001), corporate governance (Peng and Su, 2014), strategic decision making (Markovitch, Steckel and Yeung, 2005; Bakke and Whited, 2010; Foucault and Frésard, 2012; Peng and Su, 2014), product scope, growth, and valuation (Gande et al., 2009). Liquidity is a key determinant of these benefits and is cited as a primary motivator for foreign listings (e.g., Saudagaran, 1988; Saudagaran and Biddle, 1995; Blass and Yafeh, 2001; Doidge, Karolyi and Stulz, 2004; Karolyi, 2006). Yet the relation between foreignness and IPO liquidity, a key component of transaction costs in capital markets, remains largely unexamined to date.

We examine IPOs on US exchanges from 1990 to 2012, which dominate in numbers and capitalization, with two sets of findings. First, we find that foreign IPO shares are systematically less liquid than comparable domestic US IPOs. This liquidity differential indicates that foreign IPOs continue to experience frictions described in Bell et al. (2012) despite the net benefits to their listings. We argue that information asymmetries are a key source of these frictions, documenting that underpricing differentials are significant determinants of the liquidity liability. We further find that uncertainty plays a role as foreign firms with more volatile shares exhibit larger liquidity differentials than comparable domestic IPO listers. Second, we extend institutional

\footnotetext{
${ }^{1}$ Zaheer (1995: 343) defines foreignness as reflecting "all additional costs a firm operating in a market overseas incurs that a local firm would not incur", yet prior studies have focused primarily on transportation and coordination costs, unfamiliarity with foreign institutions, and perceived legitimacy of foreign firms (for a comprehensive review see Rugman, Verbeke and Nguyen, 2011).

${ }^{2}$ We define liquidity as the ease of trading a desired quantity of a specific financial asset quickly and at low cost (Kyle, 1985; Amihud and Mendelson, 1986).
} 
bonding theory regarding how a firm’s home country institutions affect its “liquidity discount” in an overseas capital market. Specifically, we provide evidence that foreign shares are not regarded differently from each other with respect to liquidity based upon their home country institutions. This finding contrasts with prior evidence for cross-listed shares, whose liquidity is strongly influenced by home country institutional characteristics.

Considered altogether, our findings reveal salient differences in liquidity between foreign and domestic IPO listings and cross-listings in the US that are consistent with related informational asymmetries, thereby serving to extend and clarify prior findings regarding the net benefits and costs of foreign listings (Bell et al., 2012). In particular, our findings document a "liability of foreignness” for foreign versus domestic US listings that in part offsets the net liquidity advantage of listing in the US rather than in a home country market. Importantly, we find in contrast to prior findings for foreign US cross-listed firms, that liquidity for foreign IPO firms is not significantly influenced by their home country institutional environments, consistent with added information asymmetry. In this regard, our findings are consistent with a domestic investor information disadvantage vis-à-vis foreign investors, irrespective of foreign locale (Van Nieuwerburgh and Veldkamp, 2009), where the absence of alternative and not perfectly connected trading venues does not impose additional liquidity costs as for cross-listed shares (Domowitz, Glen and Madhavan, 1998). Finally, we generalize the

findings by Blass and Yafeh (2001) for Israeli firms listed abroad to show that on average foreign IPO firms enjoy a higher level of liquidity in US markets than their home market liquidity.

The paper is structured as follows. The next section reviews the literature and formulates our hypotheses. The following section provides a description of the data. The empirical analysis and robustness tests appear in following sections, with the final section providing a discussion and summary.

\section{LITERATURE AND HYPOTHESES}

\section{Liquidity in IPOs}

Among factors identified by prior research as influencing firms’ decisions to list abroad, a key motivation is enhanced liquidity as confirmed by surveys of CFO intent (e.g., Saudagaran 1988; Fanto and Karmel, 1997; 
Bancel and Mittoo, 2001; Doidge et al., 2004; Karolyi, 2006). More specifically, firms that list abroad in deep and liquid markets have been found to benefit from reduced capital constraints and costs, more informative feedback from stock prices, and enhanced strategy, investment and growth options (e.g., Pagano et al., 2001; Doidge et al., 2004; Helwege, Pirinsky and Stulz, 2007; Hail and Leuz, 2009; Francis, Hasan, Lothian and Sun, 2010; Foucault and Frésard, 2012; Mortal and Reisel, 2013). More liquid shares are also associated with value-enhancing shareholders’ activism and monitoring (Faure-Grimaud and Gromb, 2004; Edmans, Fang and Zur, 2013; Norli, Ostergaard and Schindele, 2015), notably for cross-listing firms (Fresard and Salva, 2010). Nonetheless, Bell et al. (2012) argue that foreign firms also may be subject to frictions arising from information asymmetries and institutional differences when accessing overseas capital markets that offset these benefits.

Coffee (1999, 2002) and Stulz (1999) identify bonding with US institutions as a key source of these benefits for foreign firms listing in the US. In addition to legal bonding, they argue that access to reputable intermediaries and institutional investors contributes to the reduction of agency problems and information asymmetries. These benefits may extend beyond the initial offering since underwriters tend to become market makers after completing their price stabilization role (Ellis et al., 2002). In addition, specialists’ portfolios that focus on certain types of shares may improve their ability to extract information and reduce information asymmetries. Corroborating evidence indicates that firms are more likely to list in a foreign market that has the largest peer presence from the same industry and country (e.g., Caglio, Weiss Hanley; Marietta-Westberg, 2016). However, evidence is limited regarding potential offsetting effects to foreignness for IPOs, for which information availability is more limited compared to cross-listings, and which have come to dominate as a listing mode for prominent classes of foreign listers. ${ }^{3}$

Of particular relevance to foreign listings is liquidity. For cross-listings, prior studies find that foreign shares are systematically less liquid than domestic ones (Bacidore and Sofianos, 2002; Bacidore, Battalio,

\footnotetext{
${ }^{3}$ Baker, Biddle, Lowry and O'Connor (2017) observe that "whereas Chinese firm U.S. listings via reverse merger (CRMs) have dominated prior media, regulator and research attention regarding financial reporting quality, CRMs have effectively ceased, leaving listings via initial public offering (CIPOs) the relevant remaining class of Chinese firms on the U.S. exchanges.”
} 
Galpin and Jennings, 2005), with the strength of home country institutions a determinant of this liquidity (Chung, 2006; Eleswarapu and Venkataraman, 2006). Specifically, cross-listing has been found to help mitigate adverse liquidity effects of poor home country institutions (Shleifer and Wolfenzon, 2002; Stulz, 2009; Doidge, Karolyi and Stulz, 2010). However, cross-listing creates the potential for improvements or reductions in market quality depending on home-market transparency (Domowitz et al., 1998; Bacidore and Sofianos, 2002; Fernandes and Ferreira, 2008), with the presence of alternative and imperfectly connected trading venues increasing the potential for both informed trading and increased costs associated with dealing across markets (Gagnon and Karolyi, 2010). However, foreign firms listing in the US via IPOs by nature will be less influenced by home country institutions and by cross-market information flows regarding home country share trading. They also differ from cross-listers in other regards that may influence liquidity.

First, regulatory and disclosure requirements play a role in firms’ decision to list abroad (Biddle and Saudagaran, 1991). In particular, when foreign firms transition from private to public ownership in the US they must follow the same Security and Exchange Commission’s (SEC) registration procedures as domestic firms, ${ }^{4}$ and abide by the same stock exchange listing requirements. By comparison, cross-listed firms can file preliminary registration statements confidentially with the SEC, resolve many issues without public disclosure, and list with expedited exchange reviews. IPO firms listing in the US via these more stringent reporting and review requirements have thus been argued to bond more closely to US institutions relative to cross-listed firms, thereby helping to alleviate agency and asymmetric information problems and reduce their cost of capital (Stulz, 1999; Bell et al., 2012). Possible countervailing effects include the absence of prior trading history, their unfamiliarity more broadly to domestic investors, and the lack of comparable home country liquidity measures.

Second, foreign IPO shares listed and traded on US markets, while traded in a variety of alternative venues, are largely consolidated (O’Hara and Ye, 2011). This contrasts with cross-listed firms that trade simultaneously in two or more markets and may have a longer trading history in their home country markets.

\footnotetext{
${ }^{4}$ This includes publishing preliminary and subsequent amendments to the registration statements. For more details see SEC website https://www.sec.gov/divisions/corpfin/internatl/foreign-private-issuers-overview.shtml.
} 
Even so, US liquidity may be related to home institutions in terms of audit standards, legal disputes, regulation and broader reputational effects (Dyck and Zingales, 2004; Siegel, 2005).

Third, IPO shares have been found to experience different liquidity dynamics in the early months relative to non-IPO shares, and in particular, exhibit high trading volume on the NYSE and NASDAQ (e.g., Ellis et al., 2002; Corwin, Harris and Lipson, 2004). We track and plot these dynamics for our foreign and domestic IPO samples to document liquidity differences between them.

Following this reasoning, we provide initial evidence regarding the effect of foreignness on IPO liquidity by testing the following hypothesis:

Hypothesis 1a: Foreign IPOs listing in the US experience a liquidity disadvantage relative to comparable domestic IPOs.

Following Blass and Yafeh (2001), who argue that Israeli firms conduct IPOs in the US to access a larger and more sophisticated investor pool relative to their domestic market, we also investigate whether firms experience greater IPO liquidity in the US versus their home country, by testing the following hypothesis:

Hypothesis 1b: Foreign IPOs listing in the US experience a liquidity advantage relative to comparable IPOs in their home countries.

\section{The Role of Home Country Institutions}

Prior studies document for cross-listed shares that home country institutions influence their US liquidity (Shleifer and Wolfenzon, 2002; Chung, 2006; Eleswarapu and Venkataraman, 2006; Stulz, 2009; Doidge et al., 2010), with cross-listed firms from less (more) transparent locales exhibiting lower (higher) US liquidity (Domowitz et al., 1998; Bacidore and Sofianos, 2002; Fernandes and Ferreira, 2008). However, for reasons detailed above, this finding may not necessarily extend to foreign firms listing by IPO in the US, which we test using the following hypothesis in null form:

Hypothesis 2: The liquidity of foreign IPOs listing in the US is unrelated to the strength of their home institutional environment; 
where home country institutional environment is proxied using the La Porta, Lopez-De-Silanes, Shleifer and Vishny (1998) index of anti-director rights as adjusted by Spamann (2010) and the International Country Risk Guide (ICRG) Law and Order index.

\section{DATA}

\section{Matching Procedure}

Using the Security Data Corporation (SDC) New Issues database, we identify first-time issuers of ordinary shares in US markets between 1990 and 2012. To ensure that our foreign IPO sample includes only non-US firms with no prior listing in any market inside or outside of the US, we follow Bruner, Chaplinsky and Ramchand (2006) to define foreign firms as those incorporated and whose primary executive offices are located outside of the US. We eliminate warrants, units, and rights offerings, as well as utility and financial firms. Further, we exclude listings in the form of spinoffs from mergers and acquisitions or publicly listed companies. Firms that are based in the Bahamas, Cayman Islands, and Bermuda are also excluded, as they are often US firms registered in these locations for tax reasons. Finally, we exclude all firms with incomplete financial data. Selected variables are manually extracted from each foreign firm’s prospectus obtained from the SEC Edgar and Perfect Filing databases, with foreign currency figures translated into US dollars based on exchange rates disclosed in the prospectuses. Financial information for domestic and foreign US IPOs is obtained from the CRSP and Compustat databases. Institutional ownership holdings are obtained from Thomson Reuters. Additional information is obtained from the SDC Platinum database. Finally, we index the US figures to 2005 US dollar values based on the Consumer Price Index (CPI) as reported by the International Monetary Fund. A detailed description of the proxies employed and data sources are provided in the Appendix.

Our resulting sample used for matched sample comparisons contains 3,374 US IPOs, of which 393 are foreign and 2,981 are domestic. The largest industry in both subsamples is the business equipment, comprising approximately $35 \%$ of the total sample, and $34 \%$ and $41 \%$ of the domestic and foreign IPOs, respectively. Table 1 reports the distributions of foreign IPOs according to country of origin in two periodic windows, 19902001 and 2002-2012. Consistent with prior studies on foreign issuers in the US, the largest number of foreign 
IPOs in the sample is from Israel (77), followed by China (65), Canada (33), and the UK (32). ${ }^{5}$ Most IPOs (68\%) occur before 2001, reflecting the Internet and dot.com bubble and its effect on the high-tech sector that motivated many IPOs. We match each foreign IPO firm with the domestic US IPO firm with the same twodigit industry association, IPO year, and smallest absolute difference in size (log of total assets) at the end of the fiscal year preceding the IPO. For robustness, we test alternative matching procedures and we discuss these in the robustness tests section.

\section{[Table 1 about here]}

\section{Measuring Liquidity}

We measure liquidity using the Amihud (2002) ratio that estimates price sensitivity to transaction volume. Specifically, we compute the monthly average of the ratio of the daily absolute returns to the dollar volume for each stock in the sample, as follows:

$$
\begin{aligned}
\operatorname{Illiq}_{i, t} & =\frac{\mid \text { ret }_{i, t} \mid}{\text { dvol }_{i, t}} \\
I L L I Q_{i, m} & =\sum_{t=1}^{T m} \frac{\text { Illi }_{i, t, m}}{T m},
\end{aligned}
$$

where reti,t is the return of stock $i$ in day $t, d v o l i, t$ is the daily trading volume of stock $i$ in dollars and $T m$ is the number of daily observations in month $m$. We then multiply the measure by $10^{6}$. Since we are interested in liquidity, we also change the sign to obtain $L I Q i, m$, so that higher ratio values reflect higher levels of liquidity.

In a horse race exercise comparing differentliquidity measures at different frequencies, Goyenko, Holden and Trzcinka (2009) show that the Amihud ratio performs well among proxies for the price impact of transactions. To assess the robustness of our findings, we also conduct our analysis using bid-ask spreads as a proxy for liquidity as presented in the robustness tests section and Table 7.

\footnotetext{
${ }^{5}$ As robustness checks, we include in the main regressions indicator variables for IPOs from Israel, China, UK and Canada separately, then all indicators together, and separately exclude IPOs from each of these countries, with qualitatively similar findings. Results are available from the authors upon request.
} 


\section{Control variables}

Following prior studies, we introduce explanatory variables to control for other influences on liquidity. ${ }^{6}$ Specifically, we expect IPOs with more reputable underwriters (Corwin et al., 2004; Mantecon and Poon, 2009) and more insider ownership (Hahn, Ligon and Rhodes, 2013) to be associated with higher liquidity. Following Booth and Chua (1996), we also expect shares of larger IPOs, proxied by their proceeds, to be more liquid due to the ease of valuation relative to smaller deals.

A large strand of literature investigates the relationship between underpricing and secondary market liquidity. Several studies find that firms engage in higher levels of underpricing in order to offset the costs associated with information asymmetry problems and to increase market liquidity (e.g., Booth and Chua, 1996; Hahn et al., 2013). Other studies document a signaling effect of underpricing that helps to attract a larger investor base and more analyst coverage (e.g., Aggarwal, Krigman and Womack, 2002). In addition, higher liquidity is positively related to higher institutional investors' ownership since firms tend to attract institutional investors through higher initial underpricing of their shares (Zheng and Li, 2008). Overall, these studies point toward a positive relationship between underpricing and liquidity. Contrary to these works, Ellul and Pagano (2006) find a positive relationship between underpricing and the probability of informed trading, which is a proxy for illiquidity. They argue that first-day returns are offered to investors as compensation for the risk of holding shares with lower expected liquidity. A possible reason for the contradictory results may be the different market setting analyzed in Ellul and Pagano (2006). As the authors concede, they study the UK market in which underwriters are less likely to provide market-making services after the initial listing (see also Ljungqvist, 2003). In the US context, Ellis et al. (2002) document an active role of lead underwriters as subsequent market makers and suggest that a link may exist between underpricing and profitable post-IPO trading activities of underwriters. More recently, Ellis (2006) confirms a significant role of lead underwriters in post-IPO trading accounting for the growing importance of alternative trading venues such as electronic communication networks (ECNs). Another possible explanation may be related to a nonlinearity effect.

\footnotetext{
${ }^{6}$ Data sources and expected signs are provided in the Appendix.
} 
Following the observation that IPO shares are on average more liquid than non-IPO shares, Ligon and Liu (2011) note that the liquidity risk premium documented in Ellul and Pagano (2006) is likely to arise in the less liquid segment of US IPO shares. In fact, Ligon and Liu (2011) find that only the less liquid IPOs registered a drop in underpricing following improved liquidity conditions on the NASDAQ after a change in trading regulation. To account for the different trading protocols in the various trading venues of the US stock market, we control for the NYSE and NASDAQ in a robustness test and confirm the main results. ${ }^{7}$ The differing results also may be attributable to the liquidity proxies employed (see Hahn et al., 2013). Ellul and Pagano (2006) focus on the impact of informed trading on liquidity by using the probability of informed trading and the adverse selection component of the bid-ask spread. Nevertheless, liquidity is a broad concept that encompasses several dimensions (Kyle, 1985). Thus, it is reasonable that studies that do not focus on a specific information component but employ measures related to the price impact of transactions or overall transaction costs (including the inventory and market-making costs) also offer different insights (Hahn et al., 2013). For these reasons, and since we focus on the price impact of transactions captured by the Amihud (2002) measure, we expect to find a positive relationship between underpricing and liquidity. ${ }^{8}$

In addition to IPO characteristics, stock characteristics may also affect liquidity levels. Several studies have documented that assets with higher contemporaneous returns and lower volatility are more liquid (Stoll, 1978, Amihud, 2002, among others). Furthermore, recent evidence shows a positive relationship between liquidity and institutional ownership (Zheng and Li, 2008; Hahn et al., 2013). Thus, we expect shares with higher returns, lower volatility and higher institutional ownership to have a higher level of liquidity.

Table 2 presents summary statistics for each variable and the results of univariate analyses comparing the means of these variables between foreign and US domestic IPOs. On average, foreign firms are larger (SIZE), less levered (LEV), and marginally more undervalued (BtoM) than domestic US IPOs. On average, foreign IPOs are also larger in terms of proceeds (PROC) and insider ownership (INSIDER). Underpricing

\footnotetext{
${ }^{7}$ Results are not tabulated for brevity, but they are available from the authors upon request.

${ }^{8}$ Given the inconclusive evidence in the literature, we excluded underpricing from all the tests as a robustness exercise and obtained qualitatively similar results.
} 
(UP), underwriter quality (UW), and market returns prior to listing (HOT) are not statistically different. While returns (RET) and volatility (VOL) are not statistically different, on average, foreign shares have significantly less institutional ownership (HOLD) than domestic shares across all horizons.

[Table 2 about here]

Table 3 reports the correlation coefficients. As expected, we find that firm size is positively and significantly correlated with book-to-market, proceeds, and underwriter quality. In addition, larger and more leveraged firms experience lower volatility and more institutional ownership after listing. Underpricing is larger when recent market returns and insider holdings are higher. Moreover, underpricing is positively related to volatility. With respect to IPO proceeds, smaller IPOs are associated with more volatile shares and lower institutional ownership. Finally, shares with higher quality underwriters have also larger institutional ownership.

[Table 3 about here]

\section{RESULTS}

Initial evidence regarding the liquidity of foreign and matching US domestic IPOs is shown in Figure 1. Panel A illustrates that liquidity levels measured using the Amihud ratio of foreign and matching domestic IPO shares. Both exhibit higher liquidity in the immediate post-listing time period, followed by falling liquidity levels over a longer time horizon. This pattern is consistent with prior findings regarding trading volume for IPOs. In this respect, Corwin et al. (2004) show that trading volume and the level of depth of limit order books of NYSE specialists stay higher than normal for the first month of listing. For the NASDAQ, Ellis et al. (2002) find that the trading volume of newly issued shares is particularly high until it stabilizes after three months of trading. By comparison, average bid-ask spreads in Panel B begin at high levels and decline through time as found by Ellul and Pagano (2006). Importantly, both Panels A and B exhibit significant differences in liquidity between foreign and domestic US IPOs, consistent with Hypothesis 1a, with foreign (domestic) IPOs exhibiting larger Amihud ratios (bid-ask spreads) in Panels A and B, respectively. 


\section{Liquidity Differences Between Foreign and Domestic US IPOs}

To formally test whether foreign IPOs face a systematic liquidity disadvantage relative to comparable domestic IPOs, we examine liquidity differences between foreign and domestic US IPOs using both univariate and multivariate tests. As presented in Table 4 (Panel A), we find that differences are significant across all time periods, with foreign IPO shares less liquid than those of matched domestic counterparts. These findings are qualitatively unchanged if we exclude from the sample the IPOs that took place during the bubble period of 1999-2000 (as in Ljungqvist and Wilhelm Jr., 2003). ${ }^{9}$ In a robustness test reported in the robustness tests section and Table 7, we also confirm these findings for liquidity measured using the bid-ask spread.

To shed light on underlying reasons for these observed liquidity differences, and to control for other influences on liquidity, we compare foreign and matching domestic IPO firms in a multivariate setting. Specifically, we regress liquidity differences between matched domestic and foreign IPO shares on the differences in explanatory variables as follows:

$$
\begin{aligned}
\Delta L I Q_{i, m} & =\alpha_{m}+\beta_{m} \Delta F I R M_{i, m}+\gamma_{m} \Delta I P O_{i, m}+\delta_{m} \Delta S T O C K_{i, m}+\varepsilon_{m} \\
\text { for } m & =1,2,3,6,9,12,24 \text { and } 36 \text { months. }
\end{aligned}
$$

where $\Delta L I Q i, m$ is the difference between the matched domestic and foreign stock $i$ of the daily Amihud ratio averaged over month $m . \triangle F I R M$ are the differences in firm characteristics - i.e., recent sales, book-to-market, and leverage ratio. $\triangle I P O$ are the differences in IPO characteristics - i.e., underpricing, IPO proceedings, insiders, underwriter quality, and recent market returns. $\triangle S T O C K$ represents the differences in stock characteristics - i.e., return, volatility, and institutional ownership.

Table 4 (Panel B) reports results for the regression analysis. The positive and significant constant $(\alpha)$ confirms the results of the univariate analysis: a systematic positive liquidity differential exists between domestic and foreign shares. Moreover, larger differentials in underpricing are related to larger differences in liquidity between domestic and foreign shares. These findings suggest that foreign firms have to offer larger underpricing (resulting in lower underpricing differentials) in order to reduce their liquidity differentials over

\footnotetext{
${ }^{9}$ Results are unreported for brevity, but available from the authors upon request.
} 
comparable domestic firms. This effect is relevant up to one year after the IPO. Moreover, lower liquidity differentials are associated with larger differences in underwriter quality and lower differences in insider ownership up to six months following the listings. After that period, shares of the two groups share more similar liquidity levels for larger volatility differentials (i.e. foreign shares are less volatile).

[Table 4 about here]

Thus, we find that liquidity differences are related to asymmetric information, which is neither attenuated nor offset by underpricing and reputable underwriters. In addition, we find that liquidity differences are related to foreign shares' higher volatility that leads to lower liquidity levels.

\section{Global IPOs and Multiple Trading Venues}

In this section, we extend the study of the underlying reasons for these observed liquidity differences by explicitly taking into account the role of multiple trading venues. On one hand, trading across venues may lead to a wider investor base and reduce information asymmetry between market participants (e.g., dealers and investors) resulting in lower transaction costs and higher liquidity (e.g., Bacidore and Sofianos, 2002). On the other hand, prior findings suggest that the presence of alternative and imperfectly connected trading venues may increase information asymmetry between market participants and thus impose additional liquidity costs for cross-listed shares (Domowitz, Glen and Madhavan, 1998).

We estimate equation (2) for the global IPOs in our sample to determine whether foreign IPOs that list in multiple exchanges face lower liquidity disadvantages relative to comparable domestic IPOs. ${ }^{10}$ Results reported in Table 5 document the presence of a liquidity disadvantage relative to comparable domestic IPOs (Panel A), where in the multivariate setting, this liquidity disadvantage is generally weaker and declines through time (Panel B). Moreover, the two key determinants in the main analysis above are not evident for this subsample. Specifically, underpricing, underwriter rank, and volatility do not significantly influence

\footnotetext{
${ }^{10}$ Global IPOs are firms that go public in multiple exchanges at the same time. This set of firms is generally larger than foreign IPOs and they conduct larger issuing in terms of IPO proceeds. We confirm these differences for our sample in untabulated tests.
} 
liquidity differential in global IPOs. In untabulated results we also estimate equation (2) for the full sample, but excluding global IPOs, and we find that these determinants are significant and correctly signed, in line with the main results above. ${ }^{11}$

[Table 5 about here]

Overall, these findings suggest that the wider investor base and information flow that arises from the presence of multiple trading venues reduces information asymmetry and improves the liquidity of foreign stocks in the US. ${ }^{12}$

\section{A Comparison with Home Market Liquidity}

Extending the finding in the previous section that shares of foreign IPOs enjoy less liquidity than shares of comparable US domestic IPOs, we focus in this section on Hypothesis 1b, that foreign IPOs listing in the US experience a liquidity advantage relative to comparable IPOs in their home countries. Considering liquidity at issuance, we conduct two sets of comparisons. First, we compare the liquidity level of the foreign shares in the US to the market liquidity in the home stock market. Given that foreign IPO firms are generally larger than their domestic counterparts (Bruner et al., 2004; Caglio et al., 2016), we compare the liquidity of foreign IPO shares to home market liquidity measured by the value-weighted average of the Amihud ratio (changed of sign to measure liquidity) of all shares that comprise the home country stock market index. We find that the liquidity of foreign shares in the US is significantly higher than the liquidity of the home country stock market. Specifically, the average liquidity of foreign IPO shares in the first month of listing is -0.05 compared with an average home market liquidity of $-0.22 .^{13}$

Second, focusing on Canada, China, Israel, and the UK, we gather data on domestic IPOs in these markets

\footnotetext{
${ }^{11}$ For robustness, we confirm the results for the alternative liquidity measure, the bid-ask spread (untabulated).

${ }^{12}$ Comparing our results with mature cross-listed evidence in prior literature, we infer that our foreign IPO sample is sensibly less liquid than mature cross-listed stocks. Bacidore \& Sofianos (2002) report an average spread of $1.17 \%$ for non-US stocks (1.62\% for emerging non-US) listed on the NYSE in the sample period of their analysis, that is July 1998. We conduct a similar test for foreign IPOs listed in the US in 1998 and find a spread of 2.77\%. Global IPOs are different from mature cross-listers since they do not have any previous transaction history at the time of listing.

${ }^{13}$ Due to lack of data for the calculation of the Amihud ratios for certain countries, the sample size is 301 foreign IPOs.
} 
in the same year, country, and industry as the foreign IPOs in our samples. We then build the average Amihud measures of the matching domestic newly listed shares at the same horizons and compare them to the Amihud ratios of our foreign IPOs in the US. The average liquidity of US foreign IPO shares in the first month of listing is -0.16 while the average liquidity of home country IPO shares is lower at $-2.19 .{ }^{14}$ We find that on average, foreign IPOs in the US are more liquid than domestic IPOs in their home markets. Thus, even though they suffer from a "liability of foreignness”, foreign firm IPOs still enjoy higher liquidity by listing in the US rather than in their home markets.

\section{Home Country Institutions}

In this section, we consider Hypothesis 2 that the liquidity of foreign IPOs listing in the US is unrelated to the strength of their home institutional environment. We measure the strength of home institutions (HOME) using the product of two measures. The first is the La Porta, Lopez-De-Silanes, Shleifer and Vishny (1998) index of anti-director rights, as adjusted by Spamann (2010). ${ }^{15}$ The second is the International Country Risk Guide (ICRG) Law and Order index. ${ }^{16}$ We use the product of these two measures because the anti-director rights index covers only aspects of de-jure regulation captured by six sub-indices indicating the letter of the law, not its enforcement in practice (Durnev and Kim, 2005; Bruno and Claessens, 2010). By comparison, the Law and Order index assesses the de-facto law and order traditions including enforcement and legal system. We then assign a country-year score according to the year of the IPO and its home country to capture both de-jure and de-facto aspects of investor protection (Durnev and Kim, 2005; Bruno and Claessens, 2010; Bell, Filatotchev and Aguilera, 2014). We next divide the sample into strong (weak) home institutions sub-samples according to whether the country's score falls above (below/at) the sample median of the product of these two measures. The indicator HOME is set equal to one if the country's score is above the sample

\footnotetext{
${ }^{14}$ Due to lack of data availability for the matching of IPO shares, the sample is 55 foreign IPOs.

${ }^{15}$ Spamann (2010) shows that his revised index markedly differs from both the La Porta et al. (1998) original index as well as its later revision that is provided in Djankov, La Porta, Lopez-De-Silanes and Shleifer (2008).

${ }^{16}$ Retrieved from http://www.prsgroup.com/icrg.aspx. Since both Spamann (2010) and La Porta, Lopez-De-Silanes and Shleifer (2006) do not provide measures for China, for the first and second measures we use the values for China from Ding, Nowak and Zhang (2010).
} 
median and zero otherwise. ${ }^{17}$

Table 6 (Panel A) reports univariate tests for differences in means. In contrast to prior findings for crosslisted firms, the results show no significant liquidity differences between foreign IPOs listing in the US from countries with weak versus strong institutional environments.

To control for other influences on liquidity, we next the following multivariate model that includes controls and the home institutional strength estimators:

$$
\begin{aligned}
& L I Q_{i, m}=\alpha_{m}+\theta_{m} H O M E_{i, m}+\beta_{m} F I R M_{i, m}+\gamma_{m} I P O_{i, m}+\delta_{m} \text { STOCK }_{i, m}+c_{m} \text { for } m=1,2,3 \\
& 6,9,12,24,36 \text { months; }
\end{aligned}
$$

where LIQi,m is the daily Amihud ratio of foreign stock $i$ averaged over month $m$. FIRM are the firm characteristics - i.e., recent sales, book-to-market, and leverage ratio. IPO are the IPO characteristics - i.e., underpricing, IPO proceedings, insiders, underwriter quality, recent market returns, and SOX for listing following the introduction of the SOX Act. STOCK are the share characteristics - i.e., return, volatility, and institutional ownership. As presented in Table 6 (Panel B), the multivariate results confirm the univariate results in finding no significant impact of home institutional environment on the liquidity of foreign IPO shares listed in the US, consistent with Hypothesis 2.

\section{[Table 6 about here]}

Measuring liquidity alternatively using the bid-ask spreads, we find that shares of foreign firms from countries with weaker institutions are on average less liquid than those from countries with stronger institutions in the univariate tests at 2 months (at 1\% significance level), 3 months (at 1\% significance level), 6 (at 5\% significance level) months and 12 months (at 10\% significance level) after their IPO. However, these differences are insignificant in the multivariate setting and thus do not provide robust evidence of a consistent liquidity difference related to home country institutions after controlling for other liquidity determinants.

Overall, our findings for Hypotheses 1a, $1 \mathrm{~b}$ and 2 indicate that foreign firms obtain a liquidity advantage

\footnotetext{
${ }^{17}$ An alternative approach is to calculate the median score for each year and thus HOME is set to one if the country's score in a particular year is above that year's median. However, country scores are very stable and little difference results between the measures.
} 
by conducting their IPOs in the US rather than in their home country markets, they nevertheless still suffer from a "liability of foreignness" compared with US domestic IPOs that does not relate to the quality of their home institutional environment as was found previously for foreign US cross-listed shares. These findings are consistent with the theoretical model of Van Nieuwerburgh and Veldkamp (2009) that implies that since foreign listing does not solve the information disadvantage of domestic investors in the host country, they will be home biased irrespective of the origins of the foreign firm. Beyond this, we find that foreign IPO shares experience a liquidity benefit from US listings when compared with index-wide liquidity in their home markets that is not significantly influenced by home country institutional environment as found for foreign US cross-listed firms. This latter finding is consistent with added information asymmetry for foreign IPO versus cross-listings, as IPOs have no prior trading history and no cross-market liquidity measures for market participants to compare. This is in line with the findings that when foreign IPOs list in multiple markets (global IPOs), their liquidity differences decline as the presence of multiple trading venues reduces information asymmetry and improves the liquidity of foreign stocks in the US.

\section{ROBUSTNESS TESTS}

We first conduct the analysis above with the bid-ask spread as an alternative measure of transaction costs measured by subtracting the bid from ask price and scaling the difference by the mid-price (Ellul and Pagano, 2006; Chung and Zhang, 2014). ${ }^{18}$ Weconfirm that on average the bid-ask spreads of foreign IPO shares are higher than for comparable US domestic IPO shares (Table 7, Panel A). Multivariate regression results also yield qualitatively similar findings in Table 7 (Panel B). Thus, in addition to a greater price impact of transactions, foreign IPO shares have also larger bid-ask spreads than comparable US domestic shares.

[Table 7 about here]

Our results also are robust to matching foreign and US domestic shares using market capitalization at the end of the first day of trading and propensity score matching by multiple factors. With regard to the latter, we follow the propensity score matching procedure in Heckman, Ichimura and Todd (1997) and Gao, Harford

${ }^{18}$ Daily closing bid and ask prices are available from CRSP. 
and $\mathrm{Li}$ (2013) and employ a one-to-one nearest neighbor matching with replacement technique to test differences in liquidity levels between domestic and foreign US IPOs. ${ }^{19}$ Moreover, our results are robust to the exclusion of underpricing and of IPOs that took place during the bubble of 1999-2000 and to control for the different trading protocols on the NYSE and NASDAQ. Also, we confirm our results using quantile (median) regressions. As an alternative methodology, we run a full interaction model with all IPO shares and use dummies for foreign shares and again our main results are confirmed. These results are unreported for brevity, but are available from the authors on request.

Finally, we conduct a battery of robustness tests with alternative measures of home country institutions with qualitatively similar results. ${ }^{20}$ In particular, we employ other indicators including (1) a continuous variable for HOME; (2) the original La Porta et al. (1998) anti-director index in line with Chung (2006) and Eleswarapu and Venkataraman (2006); (3) the law enforcement index from La Porta et al. (1998) following Chung (2006) and Eleswarapu and Venkataraman (2006). Furthermore, we test for geographical distance, home bias, Economic Freedom index, Euromoney index, common vs. civil law, and cultural differences (Hofstede’s index following Tang and Koveos, 2008). We also follow Cumming, Johan and Li (2011) to consider (1) the price manipulation index, (2) the volume manipulation index, (3) the spoofing index, (4) the false disclosure index, (5) the market manipulation index, (6) the insider trading index, and (7) the broker-agency index, and to account for regulation changes, we consider the indexes individually and for the periods before and after the adoption in November 2007 of the Markets in Financial Instruments Directive (MiFID). Consistent with our main results, we do not find the quality of the home country regulatory system to significantly influence the liquidity differences of foreign IPO shares listed in the US.

\footnotetext{
${ }^{19}$ We also employ alternative specifications and confirm our results. These alternatives include radius matching, kernalbased and bootstrap matching when the controls for selection are based on multiple observable firm characteristics. These include the natural logarithm of total assets in the last financial year preceding the IPO, Industry and year fixed effects, market-to-book ratio in in the first day of listing, leverage ratio, market return in the 30 days preceding the IPO, insiderholding levels after the completion of the IPO, and the underpricing levels. Results are untabulated for brevity, but available from the authors upon request.

${ }^{20}$ Results are untabulated for brevity, but are available from the authors upon request.
} 


\section{DISCUSSION AND CONCLUSIONS}

This study examines the liquidity patterns of foreign IPOs in US stock markets. As such, we extend the ongoing discussion in the IB literature regarding why foreign IPO firms choose to list abroad to reveal differences between IPO and cross-listed firms. We argue that foreign IPOs are fundamentally different from cross-listed firms studied previously, combining information problems associated with both the specific lifecycle event of transitioning from private to public as well as informational and institutional differences. Whereas these features lend themselves to added bonding to the institutional environment in the US, the fact that foreign IPO firms have originated outside of the US could still subject them to a liability of foreignness in liquidity.

Using a unique matched dataset, we compare liquidity levels of different time periods up to three years post-listing of foreign and domestic IPOs in the US. We find lower liquidity in foreign relative to domestic US IPOs in all the post-IPO time periods. However, in contrast to prior literature on liquidity in cross-country and cross-listing settings, we find that in foreign IPOs listed in the US, home country institutional environments do not play a significant role in determining liquidity levels as for cross-listed US listers. In addition, we document a relationship between the IPO characteristics and liquidity differentials. Specifically, greater underpricing for foreign as opposed to domestic IPOs is associated with lower liquidity differences in their shares. Thus, foreign shares are able to enjoy similar, or higher, levels of liquidity as domestic ones when they offer investors and dealers larger initial returns. Also, consistent with mature shares, we find that higher uncertainty, measured by volatility, is associated with greater liquidity differentials. Moreover, multiple listings in various markets is associated with reduced liquidity differentials. With respect to the liquidity motivation of listing abroad, we find that foreign IPO shares are more liquid than index shares in their home markets and matching IPOs in their home countries. Thus, although foreign IPOs enjoy higher liquidity relative to their home countries, they do not fully gain the benefits associated with liquid secondary markets to the same extent as domestic US IPOs.

Collectively, these findings contribute to the debate surrounding the motivation of foreign firms to list in the US and provide useful evidence as to the applicability of certain theories such as bonding and avoidance as well as the liquidity theorem with respect to foreign IPOs. Together, our results suggest that foreign IPOs 
differ in liquidity from both cross-listed firms and from domestic US IPOs. Our findings further suggest that this effect can be managed and potentially reduced if the legal, reporting, and enforcement settings that are available to investors in the primary market are also made available in the secondary market. 


\section{REFERENCES}

Aggarwal, R. K., Krigman, L. and Womack, K. L. (2002) 'Strategic IPO underpricing, information momentum, and lockup expiration selling’, Journal of Financial Economics, 66(1), pp. 105-137.

Amihud, Y. (2002) 'Illiquidity and stock returns: cross-section and time-series effects', Journal of Financial Markets, 5(1), pp. 31-56.

Amihud, Y. and Mendelson, H. (1986) 'Asset pricing and the bid-ask spread', Journal of Financial Economics, 17(2), pp. 223-249.

Bacidore, J. M., Battalio, R., Galpin, N. and Jennings, R. (2005) 'Sources of liquidity for NYSE-listed nonUS stocks’, Journal of Banking \& Finance, 29(12), pp. 3075-3098.

Bacidore, J. M. and Sofianos, G. (2002) 'Liquidity provision and specialist trading in NYSE-listed non-US stocks’, Journal of Financial Economics, 63(1), pp. 133-158.

Baker, R. R., Biddle, G. C., Lowry, M. R. and O’Connor, N. G. (2017) ‘Ineffective Internal Control Reporting by Chinese U.S.-listed Firms', working paper.

Bakke, T. E. and Whited, T. M. (2010) 'Which firms follow the market? An analysis of corporate investment decisions’, Review of Financial Studies, 23(5), pp. 1941-1980.

Bancel, F. and Mittoo, U. R. (2001) 'European managerial perceptions of the net benefits of foreign stock listings’, European Financial Management, 7(2), pp. 213-236.

Bell, G., Filatotchev, I. and Aguilera, R. (2014) ‘Corporate governance and investors’ perceptions of foreign IPO value: An institutional perspective’, Academy of Management Journal, 57(1), pp. 301-320.

Bell, R. G., Filatotchev, I. and Rasheed, A. A. (2012) 'The liability of foreignness in capital markets: Sources and remedies’, Journal of International Business Studies, 43(2), pp. 107-122.

Biddle, G. C. and Saudagaran, S. M. (1991) 'Foreign stock listings: Benefits, costs, and the accounting policy dilemma’, Accounting Horizons, 5(3), pp. 69-80.

Blass, A. and Yafeh, Y. (2001) 'Vagabond shoes longing to stray: Why foreign firms list in the United States', Journal of Banking and Finance, 25(3), pp. 555-572.

Booth, J. R. and Chua, L. (1996) 'Ownership dispersion, costly information, and IPO underpricing', Journal of Financial Economics, 41(2), pp. 291-310.

Bruner, R., Chaplinsky, S. and Ramchand, L. (2004) 'US-bound IPOs: Issue costs and selective entry', Financial Management, 33(3), pp. 39-60.

Bruner, R., Chaplinsky, S. and Ramchand, L. (2006) 'Coming to America: IPOs from emerging market issuers’, Emerging Markets Review, 7(3), pp. 191-212.

Bruno, V. and Claessens, S. (2010) 'Corporate governance and regulation: Can there be too much of a good thing?’, Journal of Financial Intermediation, 19(4), pp. 461-482.

Caglio, C., Weiss Hanley, K. and Marietta-Westberg, J. (2013) ‘Going Public Abroad’, DERA working paper series.

Chung, H. (2006) 'Investor protection and the liquidity of cross-listed securities: Evidence from the ADR market’, Journal of Banking \& Finance, 30(5), pp. 1485-1505.

Chung, K. H. and Zhang, H. (2014) 'A simple approximation of intraday spreads using daily data', Journal of Financial Markets, 17(1), pp. 94-120.

Coffee, J. C. (1999) 'Privatization and corporate governance: The lessons from securities market failure', Journal of Corporation Law, 25(1), pp. 1-39. 
Coffee, J. C. (2002) 'Racing towards the top?: The impact of cross-listings and stock market competition on international corporate governance’, Columbia Law Review, 102(7), pp. 1757-1831.

Corwin, S. A., Harris, J. H. and Lipson, M. L. (2004) 'The development of secondary market liquidity for NYSE-listed IPOs’, Journal of Finance, 59(5), pp. 2339-2374.

Cumming, D., Johan, S. and Li, D. (2011) 'Exchange trading rules and stock market liquidity', Journal of Financial Economics, 99(3), pp. 651-671.

Ding, Y., Nowak, E. and Zhang, H. (2010) ‘Foreign vs. domestic listing: An entrepreneurial decision’, Journal of Business Venturing, 25(2), pp. 175-191.

Djankov, S., La Porta, R., Lopez-De-Silanes, F. and Shleifer, A. (2008) 'The law and economics of selfdealing', Journal of Financial Economics, 88(3), pp. 430-465.

Doidge, C. G., Karolyi, G. A. and Stulz, R. M. (2004) 'Why are foreign firms listed in the US worth more?', Journal of Financial Economics, 71(2), pp. 205-238.

Doidge, C., Karolyi, G. A. and Stulz, R. M. (2010) 'Why do foreign firms leave U.S. equity markets?', Journal of Finance, 65(4), pp. 1507-1553.

Domowitz, I., Glen, J. and Madhavan, A. (1998) 'International cross-listing and order flow migration: Evidence from an emerging market', Journal of Finance, 53(6), pp. 2001-2027.

Durnev, A. and Kim, E. (2005) 'To steal or not to steal: Firm attributes, legal environment, and valuation', Journal of Finance, 60(3), pp. 1461-1493.

Dyck, A. and Zingales, L. (2004) 'Private benefits of control: An international comparison', Journal of Finance, 59(2), pp. 537-600.

Edmans, A., Fang, V. W. and Zur, E. (2013) 'The effect of liquidity on governance', Review of Financial Studies, 26(6), pp. 1443-1482.

Eleswarapu, V. and Venkataraman, K. (2006) 'The impact of legal and political institutions on equity trading costs: A Cross-country analysis’, Review of Financial Studies, 19(3), pp. 1081-1111.

Ellis, K. (2006) 'Who trades IPOs? A close look at the first days of trading', Journal of Financial Economics, 79(2), pp. 339-368.

Ellis, K., Michaely, R. and O’Hara, M. (2002) 'The making of a dealer market: From entry to equilibrium in the trading of Nasdaq stocks', Journal of Finance, 57(5), pp. 2289-2316.

Ellul, A. and Pagano, M. (2006) 'IPO underpricing and after-market liquidity', Review of Financial Studies, 19(2), pp. 381-421.

Fanto, J. A. and Karmel, R. S. (1997) 'A report on the attitudes of foreign companies regarding a U. S. listing', Stanford Journal of Law, Business and Finance, 3(1), pp. 51-83.

Faure-Grimaud, A. and Gromb, D. (2004) 'Public trading and private incentives', Review of Financial Studies, 17(4), pp. 985-1014.

Fernandes, N. and Ferreira, M. a. (2008) 'Does international cross-listing improve the information environment', Journal of Financial Economics, 88(2), pp. 216-244.

Filatotchev, I., Bell, R. G. and Rasheed, A. A. (2016) 'Globalization of Capital Markets: Implications for Firm Strategies’, Journal of International Management, (Forthcoming).

Foucault, T. and Frésard, L. (2012) 'Cross-listing, investment sensitivity to stock price, and the learning hypothesis’, Review of Financial Studies, 25(11), pp. 3305-3350.

Francis, B. B., Hasan, I., Lothian, J. R. and Sun, X. (2010) 'The signaling hypothesis revisited: Evidence from foreign IPOs’, Journal of Financial and Quantitative Analysis, 45(1), pp. 81-106. 
Fresard, L. and Salva, C. (2010) 'The value of excess cash and corporate governance: Evidence from US cross-listings’, Journal of Financial Economics, 98(2), pp. 359-384.

Gagnon, L. and Karolyi, G. A. (2010) 'Multi-market trading and arbitrage', Journal of Financial Economics, 97(1), pp. 53-80.

Gande, A., Schenzler, C., Senbet, L. W. and Gande, A. (2009) 'Valuation effects of global diversification', Journal of International Business Studies, 40(9), pp. 1515-1532.

Gao, H., Harford, J. and Li, K. (2013) 'Determinants of corporate cash policy: Insights from private firm', Journal of Financial Economics, 109(3), pp. 623-639.

Goyenko, R. Y., Holden, C. W. and Trzcinka, C. a. (2009) ‘Do liquidity measures measure liquidity?’, Journal of Financial Economics, 92(2), pp. 153-181.

Hahn, T., Ligon, J. A. and Rhodes, H. (2013) 'Liquidity and initial public offering underpricing', Journal of Banking \& Finance, 37(12), pp. 4973-4988.

Hail, L. and Leuz, C. (2009) 'Cost of capital effects and changes in growth expectations around U.S. crosslistings’, Journal of Financial Economics, 93(3), pp. 428-454.

Heckman, J. J., Ichimura, H. and Todd, P. E. (1997) 'Matching as an econometric evaluation estimator: Evidence from evaluating a job training programme’, Review of Economic Studies, 64(4), pp. 605-654.

Helwege, J., Pirinsky, C. and Stulz, R. M. (2007) 'Why do firms become widely held? An analysis of the dynamics of corporate ownership’, Journal of Finance, 62(3), pp. 995-1029.

Karolyi, G. A. (2006) 'The world of cross-listings and cross-listings of the world: Challenging conventional wisdom’, Review of Finance, 10(1), pp. 99-152.

Kyle, A. S. (1985) ‘Continuous auctions and insider trading’, Econometrica, 53(6), pp. 1315-1335.

Ligon, J. A. and Liu, H.-C. (2011) 'The effect of the trading system on the underpricing of initial public offerings', Journal of Financial Research, 34(1), pp. 103-130.

Ljungqvist, A. (2003) 'Conflicts of interest and efficient contracting in IPOs', NYU Center for Law and Business Working Paper Series, 3.

Ljungqvist, A. and Wilhelm Jr., W. J. (2003) 'IPO pricing in the dot-com bubble', Journal of Finance, 58(2), pp. 723-752.

Mantecon, T. and Poon, P. (2009) 'An analysis of the liquidity benefits provided by secondary markets', Journal of Banking \& Finance, 33(2), pp. 335-346.

Markovitch, D. G., Steckel, J. H. and Yeung, B. (2005) 'Using Capital Markets as Market Intelligence: Evidence from the Pharmaceutical Industry’, Management Science, 51(10), pp. 1467-1480.

Mata, J. and Freitas, E. (2012) 'Foreignness and exit over the life cycle of firms', Journal of International Business Studies, 43(7), pp. 615-630.

Mortal, S. and Reisel, N. (2013) 'Capital Allocation by Public and Private Firms', Journal of Financial and Quantitative Analysis, 48(1), pp. 77-103.

Van Nieuwerburgh, S. and Veldkamp, L. (2009) 'Information immobility and the home bias puzzle’, Journal of Finance, 64(3), pp. 1187-1215.

Norli, O., Ostergaard, C. and Schindele, I. (2015) 'Liquidity and shareholder activism', Review of Financial Studies, 28(2), pp. 486-520.

O’Hara, M. and Ye, M. (2011) 'Is market fragmentation harming market quality?', Journal of Financial Economics, 100(3), pp. 459-474.

Pagano, M., Randl, O., Roell, A. A. and Zechner, J. (2001) 'What makes stock exchanges succeed? Evidence 
from cross-listing decisions’, European Economic Review, 45(4), pp. 770-782.

Peng, M. W. and Su, W. (2014) 'Cross-listing and the scope of the firm', Journal of World Business, 49(1), pp. 42-50.

La Porta, R., Lopez-De-Silanes, F. and Shleifer, A. (2006) 'What works in securities laws?', Journal of Finance, 61(1), pp. 1-32.

La Porta, R., Lopez-De-Silanes, F., Shleifer, A. and Vishny, R. W. (1998) 'Law and finance', Journal of Political Economy, 106(6), pp. 1113-1155.

Rugman, A., Verbeke, A. and Nguyen, Q. T. K. (2011) 'Fifty years of international business theory and beyond’, Management International Review, 51(6), pp. 755-786.

Saudagaran, S. M. (1988) 'An empirical study of selected factors influencing the decision to list on foreign stock exchanges’, Journal of International Business Studies, 19(1), pp. 101-127.

Shleifer, A. and Wolfenzon, D. (2002) 'Investor protection and equity markets', Journal of Financial Economics, 66(1), pp. 3-27.

Siegel, J. (2005) 'Can foreign firms bond themselves effectively by renting US securities laws?', Journal of Financial Economics, 75(2), pp. 319-359.

Spamann, H. (2010) 'The “antidirector rights index” revisited', Review of Financial Studies, 23(2), pp. 467486.

Stoll, H. R. (1978) 'The supply of dealer services in securities markets', The Journal of Finance, 33(4), pp. 1133-1151.

Stulz, R. M. (1999) 'Globalization, corporate finance, and the cost of capital', Journal of Applied Corporate Finance, 12(3), pp. 8-25.

Stulz, R. M. (2009) 'Securities laws, disclosure, and national capital markets in the age of financial globalization', Journal of Accounting Research, 47(2), pp. 349-390.

Tang, L. and Koveos, P. E. (2008) 'A framework to update Hofstede’s cultural value indices: Economic dynamics and institutional stability’, Journal of International Business Studies, 39(6), pp. 1045-1063.

Zaheer, S. (1995) 'Overcoming the liability of foreignness', Academy of Management Journal, 38(2), pp. 341-363.

Zheng, S. X. and Li, M. (2008) 'Underpricing, ownership dispersion, and aftermarket liquidity of IPO stocks', Journal of Empirical Finance, 15(3), pp. 436-454. 


\section{APPENDIX: DESCRIPTION OF VARIABLES}

\begin{tabular}{|c|c|c|c|}
\hline \multicolumn{4}{|c|}{ a. Firm characteristics } \\
\hline Variables & Measurement & Data source & Expected Sign \\
\hline SIZE & Total sales at year end prior to listing. & Compustat and IPO Prospectus & + \\
\hline BtoM & $\begin{array}{l}\text { Ratio of total asset at year end prior to listing over market } \\
\text { capitalization at issue date. }\end{array}$ & $\begin{array}{l}\text { Compustat, CRSP and IPO } \\
\text { Prospectus }\end{array}$ & - \\
\hline LEV & $\begin{array}{l}\text { Ratio of total debt over total assets at year-end prior to } \\
\text { listing. }\end{array}$ & Compustat and IPO Prospectus & - \\
\hline \multicolumn{4}{|c|}{ b. IPO characteristics } \\
\hline Variables & Measurement & Data source & Expected Sign \\
\hline UP & $\begin{array}{l}\text { First day of trading returns (underpricing) defined as the } \\
\text { percentage difference between the closing stock price and } \\
\text { the offer price at the first day of trading adjusted to market } \\
\text { returns. }\end{array}$ & $\begin{array}{l}\text { Compustat, CRSP, SDC Platinum } \\
\text { and IPO Prospectus }\end{array}$ & + \\
\hline PROC & Log of the proceedings from the IPOs. & Compustat and IPO Prospectus & + \\
\hline INSIDER & $\begin{array}{l}\text { Ownership of insiders as a percentage of total shares } \\
\text { outstanding. }\end{array}$ & $\begin{array}{l}\text { Compustat, SDC Platinum and IPO } \\
\text { Prospectus }\end{array}$ & + \\
\hline HOT & Market returns in the 30 days previous to the IPO. & CRSP & + \\
\hline UW & Underwriter Rank obtained from Jay Ritter’s website. SDC & $\begin{array}{l}\text { Platinum, IPO Prospectus and } \\
\text { Jay Ritter's website on 06/11/2014. }\end{array}$ & + \\
\hline SOX & $\begin{array}{l}\text { Dummy set to } 1 \text { if IPO takes place on or after July 2002, } \\
\text { and 0otherwise. }\end{array}$ & N/A & + \\
\hline & c. Share character & istics & \\
\hline Variables & Measurement & Data s ource & Expected Sign \\
\hline RET & Average daily returns in the month. & CRSP & + \\
\hline VOL & Monthly standard deviation of daily returns. & CRSP & - \\
\hline HOLD & $\begin{array}{l}\text { Institutional investors holding of shares over total share } \\
\text { outstanding available on a quarterly basis. }\end{array}$ & $\begin{array}{l}\text { Institutional (13F) Holdings, Thom- } \\
\text { son Reuters }\end{array}$ & + \\
\hline
\end{tabular}


Table 1 Foreign IPOs by Country and Time Period.

\begin{tabular}{|c|c|c|c|c|c|}
\hline & $1990-2001$ & 2002-2012 & & 1990-2001 & 2002-2012 \\
\hline Africa & 1 & 1 & Europe & 185 & 41 \\
\hline \multirow[t]{2}{*}{ South Africa } & 1 & 1 & Austria & 1 & 0 \\
\hline & & & Belgium & 2 & 0 \\
\hline Americas & 35 & 8 & Denmark & 1 & 0 \\
\hline Argentina & 2 & 1 & Finland & 1 & 0 \\
\hline Brazil & 1 & 0 & France & 14 & 0 \\
\hline Canada & 26 & 7 & Germany & 7 & 0 \\
\hline Chile & 3 & 0 & Greece & 3 & 12 \\
\hline Mexico & 3 & 0 & Hungary & 1 & 0 \\
\hline \multirow[t]{2}{*}{ Panama } & 2 & 0 & Iceland & 1 & 0 \\
\hline & & & Ireland & 8 & 3 \\
\hline Asia & 43 & 73 & Israel & 62 & 15 \\
\hline China & 7 & 58 & Italy & 7 & 1 \\
\hline Hong Kong & 17 & 4 & Luxembourg & 2 & 0 \\
\hline India & 2 & 2 & Netherlands & 26 & 4 \\
\hline Indonesia & 1 & 0 & Norway & 1 & 0 \\
\hline Japan & 2 & 0 & Poland & 1 & 0 \\
\hline Jordan & 1 & 0 & Portugal & 1 & 0 \\
\hline Philippines & 1 & 0 & Russia & 2 & 3 \\
\hline Singapore & 6 & 2 & Spain & 2 & 0 \\
\hline South Korea & 4 & 4 & Sweden & 3 & 0 \\
\hline \multirow[t]{2}{*}{ Taiwan } & 2 & 3 & Switzerland & 7 & 1 \\
\hline & & & United Kingdom & 30 & 2 \\
\hline Oceania & 6 & 0 & & & \\
\hline Australia & 3 & 0 & & & \\
\hline New Zealand & 3 & 0 & & & \\
\hline
\end{tabular}

Notes: The table reports the number of foreign IPOs in our sample by country and time period sorted by region. 
Table 2 Descriptive Statistics of Variables.

\begin{tabular}{lccccccc}
\hline \hline & \multicolumn{2}{c}{ Domestic } & & & Foreign & \\
& & & & & & & \\
& count & mean & sd & count & mean & sd & -value \\
\cline { 2 - 8 } SIZE & 2156 & 16.71 & 4.02 & 357 & 17.33 & 3.32 & 0.01 \\
BtoM & 2156 & 0.40 & 0.59 & 357 & 0.47 & 1.26 & 0.09 \\
LEV & 2156 & 0.26 & 0.43 & 357 & 0.18 & 0.33 & 0.00 \\
UP & 2156 & 0.24 & 0.41 & 357 & 0.26 & 0.46 & 0.64 \\
PROC & 2156 & 17.81 & 0.87 & 357 & 18.24 & 1.65 & 0.00 \\
INSIDER & 2156 & 0.71 & 0.14 & 357 & 0.73 & 0.14 & 0.02 \\
HOT & 2156 & 0.03 & 0.06 & 357 & 0.03 & 0.08 & 0.56 \\
UW & 2104 & 7.76 & 1.74 & 357 & 7.73 & 2.21 & 0.42 \\
RET1m & 2111 & 0.08 & 1.13 & 356 & 0.03 & 2.58 & 0.47 \\
RET2m & 2111 & -0.05 & 1.02 & 356 & -0.07 & 1.07 & 0.51 \\
RET3m & 2111 & 0.04 & 0.99 & 356 & 0.02 & 1.04 & 0.71 \\
RET6m & 2110 & -0.11 & 1.05 & 356 & -0.19 & 1.02 & 0.10 \\
RET9m & 2101 & -0.10 & 1.04 & 356 & -0.21 & 0.99 & 0.07 \\
RET12m & 2076 & -0.09 & 1.01 & 354 & -0.20 & 1.05 & 0.05 \\
RET24m & 1849 & -0.07 & 1.04 & 341 & -0.11 & 1.13 & 0.50 \\
RET36m & 1525 & 0.02 & 1.05 & 319 & -0.02 & 1.04 & 0.58 \\
VOL1m & 2111 & 4.21 & 2.47 & 356 & 4.06 & 2.89 & 0.34 \\
VOL2m & 2109 & 4.23 & 2.21 & 356 & 4.30 & 2.48 & 0.41 \\
VOL3m & 2110 & 4.29 & 2.26 & 356 & 4.17 & 2.25 & 0.46 \\
VOL6m & 2109 & 4.53 & 2.72 & 356 & 4.36 & 2.44 & 0.29 \\
VOL9m & 2099 & 4.49 & 2.59 & 356 & 4.45 & 2.72 & 0.88 \\
VOL12m & 2085 & 4.54 & 2.65 & 354 & 4.63 & 3.11 & 0.34 \\
VOL24m & 1860 & 4.51 & 2.91 & 341 & 4.75 & 3.04 & 0.07 \\
VOL36m & 1574 & 4.53 & 2.91 & 318 & 4.84 & 4.14 & 0.06 \\
HOLD1-3m & 2156 & 0.22 & 0.17 & 357 & 0.09 & 0.15 & 0.00 \\
HOLD6m & 2156 & 0.18 & 0.13 & 357 & 0.11 & 0.17 & 0.00 \\
HOLD9m & 2156 & 0.20 & 0.15 & 357 & 0.13 & 0.18 & 0.00 \\
HOLD12m & 2156 & 0.33 & 0.23 & 357 & 0.13 & 0.19 & 0.00 \\
HOLD24m & 2156 & 0.34 & 0.28 & 357 & 0.13 & 0.19 & 0.00 \\
\hline \hline & 2156 & 0.31 & 0.31 & 357 & 0.12 & 0.21 & 0.00 \\
\hline
\end{tabular}

Notes: Descriptive statistics of the explanatory variables for all domestic and foreign shares in our sample in Panel A and the matched sample in Panel B. SIZE is total sales of firms at year-end prior to listing, BtoM is book-to-market ratio at year-end prior to listing, LEV is total debt over total assets at year-end prior to listing, UP is underpricing, PROC is log of the proceeds from the IPO, INSIDER is ratio of shares owned by insiders over total shares outstanding, HOT is market returns in the 30 days prior to listing, UW is underwriter quality, RET is monthly average returns of the shares, VOL is monthly standard deviation of daily returns and HOLD is share of institutional ownership. The last three measures are multiplied by $10^{2}$. More details of the explanatory variables are reported in the Appendix. The last column reports the $p$-values of the t-test for the significance of the difference between the mean values from zero of the variables for domestic and foreign shares. 
Table 3 Correlation Matrix.

\begin{tabular}{|c|c|c|c|c|c|c|c|c|c|c|}
\hline & SIZE & BtoM & LEV & UP & PROC & INSIDER & НОт & UW & RET & VOL \\
\hline BtoM & 0.28 & & & & & & & & & \\
\hline LEV & 0.08 & 0.14 & & & & & & & & \\
\hline UP & -0.04 & -0.08 & -0.12 & & & & & & & \\
\hline PROC & 0.23 & 0.13 & 0.10 & 0.08 & & & & & & \\
\hline INSIDER & -0.05 & -0.23 & -0.11 & 0.22 & -0.02 & & & & & \\
\hline HОТ & -0.03 & -0.03 & -0.02 & 0.24 & -0.01 & -0.02 & & & & \\
\hline UW & 0.17 & 0.05 & 0.03 & 0.10 & 0.55 & 0.12 & -0.04 & & & \\
\hline RET & 0.02 & 0.01 & 0.00 & -0.05 & -0.01 & 0.01 & -0.03 & 0.02 & & \\
\hline VOL & -0.19 & -0.17 & -0.10 & 0.26 & -0.16 & 0.13 & 0.07 & -0.07 & -0.06 & \\
\hline HOLD & 0.12 & 0.11 & 0.11 & -0.02 & 0.27 & -0.16 & -0.01 & 0.26 & 0.04 & -0.17 \\
\hline
\end{tabular}

Notes: Correlation coefficients of the variables, averaged across foreign and matched domestic IPOs, are reported in the table. SIZE is total sales of firms at year-end prior to listing, BtoM is book-to-market ratio at year-end prior to listing, LEV is total debt over total assets at year-end prior to listing, UP is underpricing, HOT is market returns in the 30 days prior to listing, PROC is log of proceeds from the IPO, INSIDER is ratio of shares owned by insiders over total shares outstanding, UW is underwriter quality, RET is monthly average returns of shares, VOL is monthly standard deviation of daily returns, and HOLD is share of institutional ownership. The last three measures are multiplied by $10^{2}$. More details of the explanatory variables are reported in the Appendix. 
Table 4 Liquidity Differences Between Foreign and Domestic US IPOs.

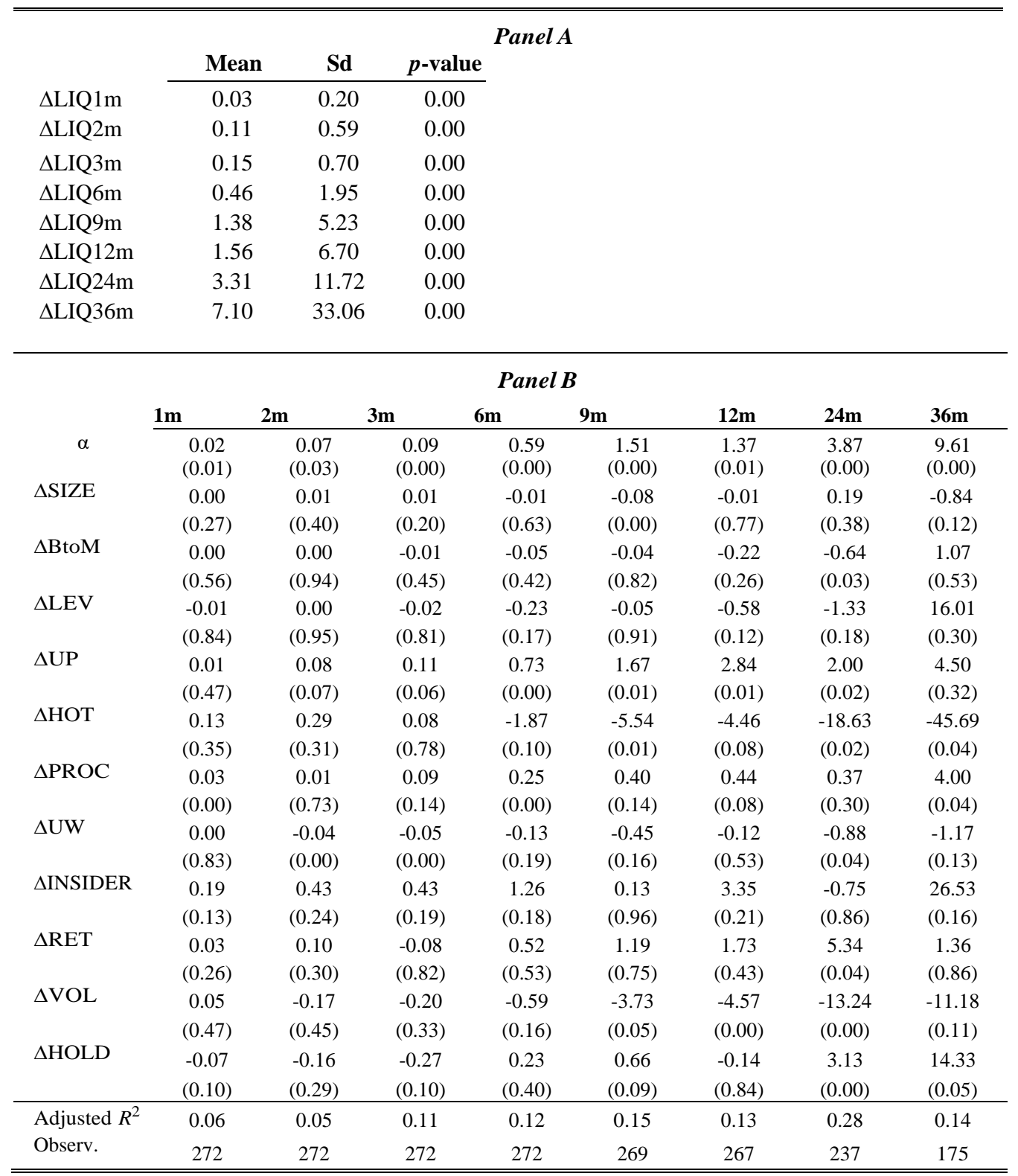

Notes: Panel A reports the univariate test of differences in means of domestic and foreign liquidity measured by the Amihud ratio of the absolute daily returns over dollar trading volume averaged across each month for each stock, changed of sign and multiplied by $10^{6}$. The last column reports the $p$-values. Panel B reports the results of regression (2) at different horizons after listing:

$$
\begin{aligned}
\Delta L I Q_{i, m} & =\alpha_{m}+\beta_{m} \Delta F I R M_{i, m}+\gamma_{m} \Delta I P O_{i, m}+\delta_{m} \Delta S T O C K_{i, m}+\varepsilon_{m} \\
\text { for } m & =1,2,3,6,9,12,24 \text { and } 36 \text { months. }
\end{aligned}
$$

$\Delta$ indicates differences between the matching domestic and foreign variables. Firm characteristic variables are: SIZE for size, BtoM for book to market, LEV for leverage ratio. IPO characteristics variables are: UP for underpricing, PROC for IPO proceedings, INSIDER for insider ownership, HOT for market returns in the month prior the listing, UW for underwriter quality. Stock characteristics variables are: RET for return, VOL for volatility, HOLD for institutional investor ownership. More details of the explanatory variables are reported in the Appendix. p-values are reported below the coefficients. 
Table 5 Global IPOs.

\begin{tabular}{|c|c|c|c|c|c|c|c|c|}
\hline \multicolumn{9}{|c|}{ Panel A } \\
\hline & Mean & Sd & $p$-value & & & & & \\
\hline$\Delta \mathrm{LIQ} 1 \mathrm{~m}$ & 0.04 & 0.23 & 0.04 & & & & & \\
\hline$\Delta \mathrm{LIQ} 2 \mathrm{~m}$ & 0.13 & 0.69 & 0.04 & & & & & \\
\hline$\Delta$ LIQ3m & 0.12 & 0.77 & 0.07 & & & & & \\
\hline$\Delta$ LIQ6m & 0.43 & 2.57 & 0.06 & & & & & \\
\hline$\Delta$ LIQ9m & 1.12 & 5.47 & 0.03 & & & & & \\
\hline$\Delta \mathrm{LIQ} 12 \mathrm{~m}$ & 1.79 & 7.74 & 0.02 & & & & & \\
\hline$\Delta \mathrm{LIQ} 24 \mathrm{~m}$ & 2.75 & 8.87 & 0.00 & & & & & \\
\hline \multirow[t]{3}{*}{$\Delta$ LIQ36m } & 7.89 & 39.35 & 0.07 & & & & & \\
\hline & \multicolumn{7}{|c|}{ Panel B } & \\
\hline & $1 \mathrm{~m}$ & $2 m$ & $3 \mathrm{~m}$ & $6 \mathrm{~m}$ & $9 m$ & $12 \mathrm{~m}$ & $24 \mathrm{~m}$ & $36 \mathrm{~m}$ \\
\hline \multirow[t]{2}{*}{$\alpha$} & 0.035 & 0.14 & 0.23 & 0.84 & 2.79 & 3.35 & 3.14 & 2.36 \\
\hline & $(0.75)$ & $(0.54)$ & $(0.29)$ & $(0.11)$ & $(0.10)$ & $(0.05)$ & $(0.05)$ & $(0.39)$ \\
\hline \multirow{2}{*}{$\Delta \mathrm{SIZE}$} & 0.00 & -0.00 & -0.01 & -0.34 & -0.10 & -0.12 & 0.049 & 1.20 \\
\hline & $(0.92)$ & $(0.77)$ & $(0.57)$ & $(0.38)$ & $(0.11)$ & $(0.46)$ & $(0.71)$ & $(0.39)$ \\
\hline \multirow[t]{2}{*}{$\Delta$ BtoM } & -0.00 & 0.02 & -0.04 & -0.06 & 0.34 & -0.12 & -0.32 & -1.87 \\
\hline & $(0.86)$ & $(0.74)$ & $(0.24)$ & $(0.71)$ & $(0.21)$ & $(0.79)$ & $(0.04)$ & $(0.46)$ \\
\hline \multirow[t]{2}{*}{$\Delta \mathrm{LEV}$} & 0.02 & 0.18 & -0.02 & 0.22 & 1.02 & 0.08 & -0.23 & -2.66 \\
\hline & $(0.61)$ & $(0.15)$ & (0.89) & $(0.50)$ & $(0.09)$ & $(0.90)$ & $(0.74)$ & $(0.64)$ \\
\hline \multirow[t]{2}{*}{$\Delta \mathrm{UP}$} & -0.00 & 0.02 & 0.20 & 0.89 & 1.16 & 3.40 & 3.89 & 21.59 \\
\hline & $(0.95)$ & $(0.87)$ & $(0.34)$ & $(0.10)$ & $(0.25)$ & $(0.23)$ & $(0.01)$ & $(0.32)$ \\
\hline \multirow[t]{2}{*}{$\Delta \mathrm{HOT}$} & 0.34 & 0.89 & -0.43 & -4.63 & -7.40 & -18.21 & -35.11 & -70.40 \\
\hline & $(0.05)$ & $(0.12)$ & (0.53) & $(0.15)$ & $(0.21)$ & $(0.03)$ & $(0.18)$ & $(0.45)$ \\
\hline \multirow[t]{2}{*}{$\triangle \mathrm{PROC}$} & 0.02 & 0.04 & 0.08 & 0.07 & 0.54 & 0.27 & 0.41 & -0.34 \\
\hline & (0.69) & (0.69) & $(0.51)$ & $(0.84)$ & $(0.40)$ & $(0.75)$ & $(0.33)$ & $(0.83)$ \\
\hline \multirow[t]{2}{*}{$\Delta \mathrm{UW}$} & -0.03 & -0.02 & -0.11 & -0.24 & -0.65 & 0.86 & -0.20 & 0.77 \\
\hline & $(0.51)$ & $(0.81)$ & $(0.16)$ & $(0.27)$ & $(0.24)$ & $(0.14)$ & $(0.40)$ & $(0.54)$ \\
\hline \multirow[t]{2}{*}{$\triangle I N S I D E R$} & 0.33 & 1.14 & 0.41 & 0.94 & 0.50 & 0.58 & 2.36 & -5.59 \\
\hline & $(0.00)$ & $(0.10)$ & $(0.21)$ & (0.13) & $(0.75)$ & $(0.74)$ & (0.59) & $(0.66)$ \\
\hline \multirow[t]{2}{*}{$\triangle \mathrm{RET}$} & 0.08 & 1.33 & 1.08 & 0.77 & 1.99 & -5.49 & 7.84 & -7.44 \\
\hline & $(0.34)$ & $(0.05)$ & $(0.22)$ & $(0.46)$ & $(0.76)$ & $(0.43)$ & $(0.50)$ & $(0.76)$ \\
\hline \multirow[t]{2}{*}{$\Delta \mathrm{VOL}$} & -0.04 & -0.76 & -0.57 & -1.63 & -2.23 & -9.46 & -7.15 & 0.11 \\
\hline & $(0.81)$ & $(0.25)$ & $(0.29)$ & $(0.12)$ & $(0.25)$ & $(0.01)$ & $(0.02)$ & $(0.95)$ \\
\hline \multirow[t]{2}{*}{$\triangle \mathrm{HOLD}$} & -0.17 & -0.51 & -0.31 & -0.27 & 2.39 & -0.31 & 2.19 & -13.55 \\
\hline & $(0.11)$ & $(0.26)$ & $(0.28)$ & $(0.69)$ & $(0.16)$ & $(0.93)$ & $(0.48)$ & $(0.40)$ \\
\hline Adjusted $R^{2}$ & 0.18 & 0.19 & 0.18 & 0.20 & 0.18 & 0.29 & 0.43 & 0.25 \\
\hline Observ. & 73 & 73 & 73 & 73 & 71 & 71 & 64 & 40 \\
\hline
\end{tabular}

Notes: For the foreign IPOs that list in multiple markets, Panel A reports the univariate test of differences in means of domestic and foreign liquidity. The last column reports the $p$-values. Panel B reports the results of regression (2) at different horizons after listing:

$$
\begin{aligned}
\Delta L I Q_{i, m} & =\alpha_{m}+\beta_{m} \Delta F I R M_{i, m}+\gamma_{m} \Delta I P O_{i, m}+\delta_{m} \Delta S T O C K_{i, m}+\varepsilon_{m} \\
\text { for } m & =1,2,3,6,9,12,24 \text { and } 36 \text { months. }
\end{aligned}
$$

$\Delta$ indicates differences between the matching domestic and foreign variables. Firm characteristic variables are: SIZE for size, BtoM for book to market, LEV for leverage ratio. IPO characteristics variables are: UP for underpricing, PROC for IPO proceedings, INSIDER for insider ownership, HOT for market returns in the month prior the listing, UW for underwriter quality. Stock characteristics variables are: RET for return, VOL for volatility, HOLD for institutional investor ownership. More details of the explanatory variables are reported in the Appendix. $p$-values are reported below the coefficients. 
Table 6 Home country institutions.

\begin{tabular}{|c|c|c|c|c|c|c|c|c|}
\hline \multicolumn{9}{|c|}{ Panel A } \\
\hline & \multicolumn{2}{|c|}{ Weak } & \multicolumn{2}{|c|}{ Strong } & \multirow[b]{2}{*}{$p$-value } & & & \\
\hline & count & mean & count & mean & & & & \\
\hline LIQ1m & 178 & -0.06 & 160 & -0.08 & 0.69 & & & \\
\hline LIQ2m & 178 & -0.16 & 160 & -0.22 & 0.39 & & & \\
\hline LIQ3m & 178 & -0.19 & 160 & -0.30 & 0.15 & & & \\
\hline LIQ6m & 178 & -0.62 & 160 & -0.80 & 0.07 & & & \\
\hline LIQ9m & 178 & -1.48 & 160 & -1.68 & 0.16 & & & \\
\hline LIQ12m & 177 & -1.69 & 159 & -1.93 & 0.23 & & & \\
\hline LIQ24m & 170 & -4.23 & 154 & -4.08 & 0.56 & & & \\
\hline LIQ36m & 154 & -4.37 & 148 & -9.28 & 0.01 & & & \\
\hline \multicolumn{9}{|c|}{ Panel B } \\
\hline & $1 \mathrm{~m}$ & $2 m$ & $3 m$ & $6 \mathrm{~m}$ & $9 m$ & $12 \mathrm{~m}$ & $24 m$ & $36 \mathrm{~m}$ \\
\hline HOME & $\begin{array}{l}-0.00 \\
(0.58)\end{array}$ & $\begin{array}{c}-0.00 \\
(0.55)\end{array}$ & $\begin{array}{c}-0.01 \\
(0.08)\end{array}$ & $\begin{array}{c}-0.01 \\
(0.39)\end{array}$ & $\begin{array}{c}-0.01 \\
(0.69)\end{array}$ & $\begin{array}{c}-0.03 \\
(0.28)\end{array}$ & $\begin{array}{l}-0.01 \\
(0.42)\end{array}$ & $\begin{array}{l}-0.13 \\
(0.59)\end{array}$ \\
\hline SIZE & $\begin{array}{l}-0.00 \\
(0.46)\end{array}$ & $\begin{array}{c}0.03 \\
(0.24)\end{array}$ & $\begin{array}{c}0.01 \\
(0.52)\end{array}$ & $\begin{array}{l}-0.01 \\
(0.42)\end{array}$ & $\begin{array}{l}-0.02 \\
(0.45)\end{array}$ & $\begin{array}{l}-0.02 \\
(0.70)\end{array}$ & $\begin{array}{c}0.34 \\
(0.48)\end{array}$ & $\begin{array}{c}-0.44 \\
(0.25)\end{array}$ \\
\hline BtoM & $\begin{array}{l}-0.00 \\
(0.50)\end{array}$ & $\begin{array}{l}-0.01 \\
(0.83)\end{array}$ & $\begin{array}{c}0.00 \\
(0.94)\end{array}$ & $\begin{array}{l}-0.02 \\
(0.70)\end{array}$ & $\begin{array}{l}-0.04 \\
(0.77)\end{array}$ & $\begin{array}{l}-0.12 \\
(0.89)\end{array}$ & $\begin{array}{l}-0.13 \\
(0.90)\end{array}$ & $\begin{array}{l}-1.17 \\
(0.53)\end{array}$ \\
\hline LEV & $\begin{array}{c}0.04 \\
(0.22)\end{array}$ & $\begin{array}{c}0.06 \\
(0.10)\end{array}$ & $\begin{array}{c}0.13 \\
(0.08)\end{array}$ & $\begin{array}{c}0.37 \\
(0.29)\end{array}$ & $\begin{array}{c}1.13 \\
(0.15)\end{array}$ & $\begin{array}{c}-0.11 \\
(0.55)\end{array}$ & $\begin{array}{l}-5.48 \\
(0.09)\end{array}$ & $\begin{array}{c}3.98 \\
(0.60)\end{array}$ \\
\hline UP & $\begin{array}{c}0.04 \\
(0.13)\end{array}$ & $\begin{array}{c}0.19 \\
(0.03)\end{array}$ & $\begin{array}{c}0.20 \\
(0.05)\end{array}$ & $\begin{array}{c}0.97 \\
(0.00)\end{array}$ & $\begin{array}{c}2.26 \\
(0.00)\end{array}$ & $\begin{array}{c}3.61 \\
(0.00)\end{array}$ & $\begin{array}{c}2.62 \\
(0.08)\end{array}$ & $\begin{array}{c}6.89 \\
(0.13)\end{array}$ \\
\hline PROC & $\begin{array}{c}0.01 \\
(0.12)\end{array}$ & $\begin{array}{l}-0.02 \\
(0.58)\end{array}$ & $\begin{array}{c}0.01 \\
(0.14)\end{array}$ & $\begin{array}{l}-0.01 \\
(0.13)\end{array}$ & $\begin{array}{c}0.11 \\
(0.06)\end{array}$ & $\begin{array}{c}0.32 \\
(0.01)\end{array}$ & $\begin{array}{c}0.11 \\
(0.48)\end{array}$ & $\begin{array}{l}-0.05 \\
(0.17)\end{array}$ \\
\hline INSIDER & $\begin{array}{c}0.20 \\
(0.10)\end{array}$ & $\begin{array}{c}0.35 \\
(0.26)\end{array}$ & $\begin{array}{c}0.40 \\
(0.06)\end{array}$ & $\begin{array}{c}0.35 \\
(0.53)\end{array}$ & $\begin{array}{c}0.30 \\
(0.99)\end{array}$ & $\begin{array}{c}3.54 \\
(0.15)\end{array}$ & $\begin{array}{l}-2.78 \\
(0.74)\end{array}$ & $\begin{array}{c}7.10 \\
(0.44)\end{array}$ \\
\hline HOT & $\begin{array}{c}0.07 \\
(0.99)\end{array}$ & $\begin{array}{c}0.79 \\
(0.37)\end{array}$ & $\begin{array}{c}0.47 \\
(0.42)\end{array}$ & $\begin{array}{c}0.86 \\
(0.49)\end{array}$ & $\begin{array}{l}-6.10 \\
(0.53)\end{array}$ & $\begin{array}{l}-2.95 \\
(0.78)\end{array}$ & $\begin{array}{c}2.49 \\
(0.70)\end{array}$ & $\begin{array}{l}-18.45 \\
(0.30)\end{array}$ \\
\hline UW & $\begin{array}{c}0.02 \\
(0.21)\end{array}$ & $\begin{array}{c}0.07 \\
(0.01)\end{array}$ & $\begin{array}{c}0.08 \\
(0.01)\end{array}$ & $\begin{array}{c}0.22 \\
(0.02)\end{array}$ & $\begin{array}{c}0.41 \\
(0.02)\end{array}$ & $\begin{array}{c}0.16 \\
(0.88)\end{array}$ & $\begin{array}{c}0.93 \\
(0.08)\end{array}$ & $\begin{array}{c}1.99 \\
(0.22)\end{array}$ \\
\hline SOX & $\begin{array}{c}0.04 \\
(0.44)\end{array}$ & $\begin{array}{c}0.11 \\
(0.10)\end{array}$ & $\begin{array}{c}0.17 \\
(0.38)\end{array}$ & $\begin{array}{c}0.57 \\
(0.50)\end{array}$ & $\begin{array}{c}2.26 \\
(0.17)\end{array}$ & $\begin{array}{c}0.63 \\
(0.71)\end{array}$ & $\begin{array}{c}4.65 \\
(0.36)\end{array}$ & $\begin{array}{c}4.00 \\
(0.80)\end{array}$ \\
\hline RET & $\begin{array}{c}0.00 \\
(0.77)\end{array}$ & $\begin{array}{c}0.04 \\
(0.49)\end{array}$ & $\begin{array}{l}-0.03 \\
(0.97)\end{array}$ & $\begin{array}{c}0.16 \\
(0.92)\end{array}$ & $\begin{array}{c}0.04 \\
(0.37)\end{array}$ & $\begin{array}{c}0.60 \\
(0.29)\end{array}$ & $\begin{array}{c}0.81 \\
(0.32)\end{array}$ & $\begin{array}{c}1.21 \\
(0.83)\end{array}$ \\
\hline VOL & $\begin{array}{l}-0.00 \\
(0.59)\end{array}$ & $\begin{array}{l}-0.03 \\
(0.31)\end{array}$ & $\begin{array}{l}-0.06 \\
(0.15)\end{array}$ & $\begin{array}{l}-0.22 \\
(0.01)\end{array}$ & $\begin{array}{l}-0.52 \\
(0.05)\end{array}$ & $\begin{array}{l}-0.71 \\
(0.03)\end{array}$ & $\begin{array}{l}-2.13 \\
(0.00)\end{array}$ & $\begin{array}{c}-2.72 \\
(0.03)\end{array}$ \\
\hline HOLD & $\begin{array}{c}0.10 \\
(0.05)\end{array}$ & $\begin{array}{c}0.30 \\
(0.04)\end{array}$ & $\begin{array}{c}0.19 \\
(0.03)\end{array}$ & $\begin{array}{c}0.01 \\
(0.95)\end{array}$ & $\begin{array}{c}1.82 \\
(0.44)\end{array}$ & $\begin{array}{l}-0.12 \\
(0.95)\end{array}$ & $\begin{array}{c}3.87 \\
(0.26)\end{array}$ & $\begin{array}{c}2.71 \\
(0.68)\end{array}$ \\
\hline Adjusted $R^{2}$ & 0.07 & 0.12 & 0.16 & 0.19 & 0.17 & 0.20 & 0.34 & 0.20 \\
\hline Observ & 337 & 337 & 337 & 337 & 337 & 335 & 323 & 300 \\
\hline
\end{tabular}

Notes: Panel A reports the univariate test of differences in means. The last column reports the $p$-values. Panel B reports the results of regression (3) at different horizons after listing:

$$
\begin{aligned}
& L I Q_{i, m}=\alpha_{m}+\theta_{m} H O M E_{i, m}+\beta_{m} \text { FIRM }_{i, m}+\gamma_{m} I P O_{i, m}+\delta_{m} S T O C K_{i, m}+\varepsilon_{m} \\
& \text { for } m=1,2,3,6,9,12,24 \text { and } 36 \text { months. }
\end{aligned}
$$

The regression is estimated at different horizons after listing and the results are reported in different columns. HOME is the indicator of home country institutions. Firm characteristic variables are: SIZE for size, BtoM for book to market, LEV for leverage ratio. IPO characteristics variables are: UP for underpricing, PROC for IPO proceedings, INSIDER for insider ownership, HOT for market returns in the month prior the listing, UW for underwriter quality, SOX for listing following the introduction of the SOX Act. Stock characteristics variables are: RET for return, VOL for volatility, HOLD for institutional investor ownership. More details of the explanatory variables are reported in the Appendix. $p$-values are reported below the coefficients. 
Table 7 Spreads as Alternative Liquidity Measures.

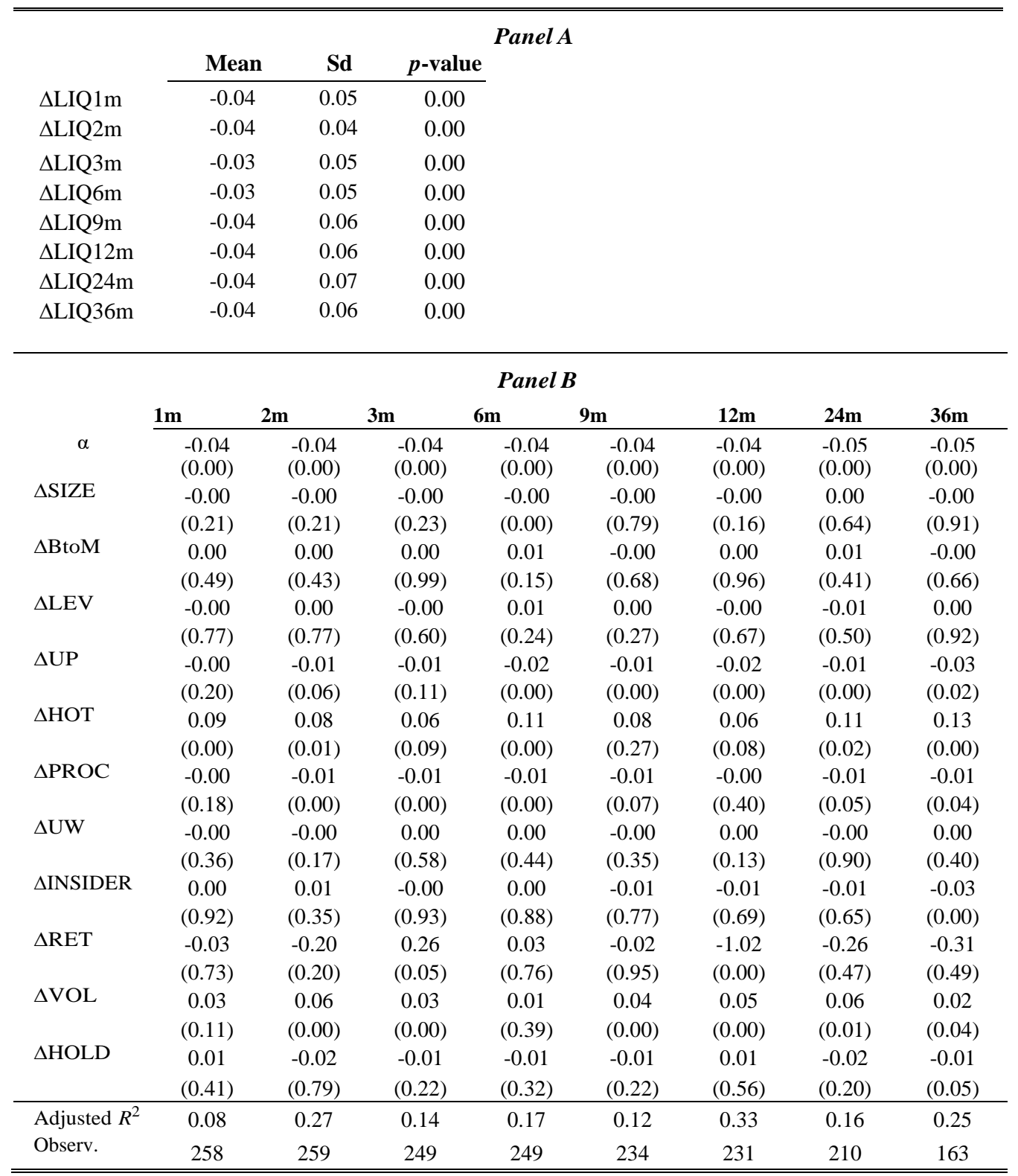

Notes: Panel A reports the univariate test of differences in means of domestic and foreign spreads. The last column reports the $p$-values. Panel B reports the results of regression (2) at different horizons after listing:

$$
\begin{aligned}
\Delta L I Q_{i, m} & =\alpha_{m}+\beta_{m} \Delta F I R M_{i, m}+\gamma_{m} \Delta I P O_{i, m}+\delta_{m} \Delta S T O C K_{i, m}+\varepsilon_{m} \\
\text { for } m & =1,2,3,6,9,12,24 \text { and } 36 \text { months. }
\end{aligned}
$$

$\Delta$ indicates differences between the matching domestic and foreign variables. Firm characteristic variables are: SIZE for size, BtoM for book to market, LEV for leverage ratio. IPO characteristics variables are: UP for underpricing, PROC for IPO proceedings, INSIDER for insider ownership, HOT for market returns in the month prior the listing, UW for underwriter quality. Stock characteristics variables are: RET for return, VOL for volatility, HOLD for institutional investor ownership. More details of the explanatory variables are reported in the Appendix. $p$-values are reported below the coefficients. 
Figure 1 Liquidity of shares for foreign and matching US domestic IPOs.

Panel A: Amihud ratio

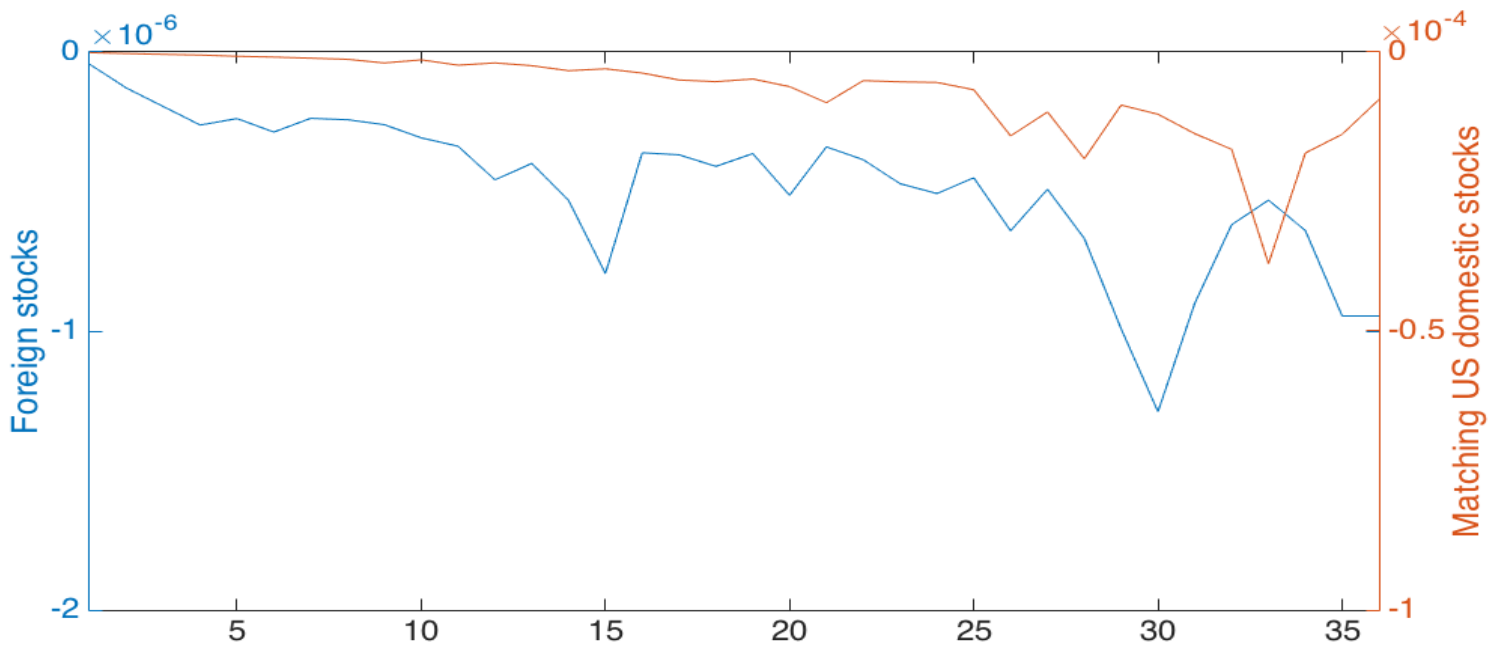

Panel B: Bid-ask spreads

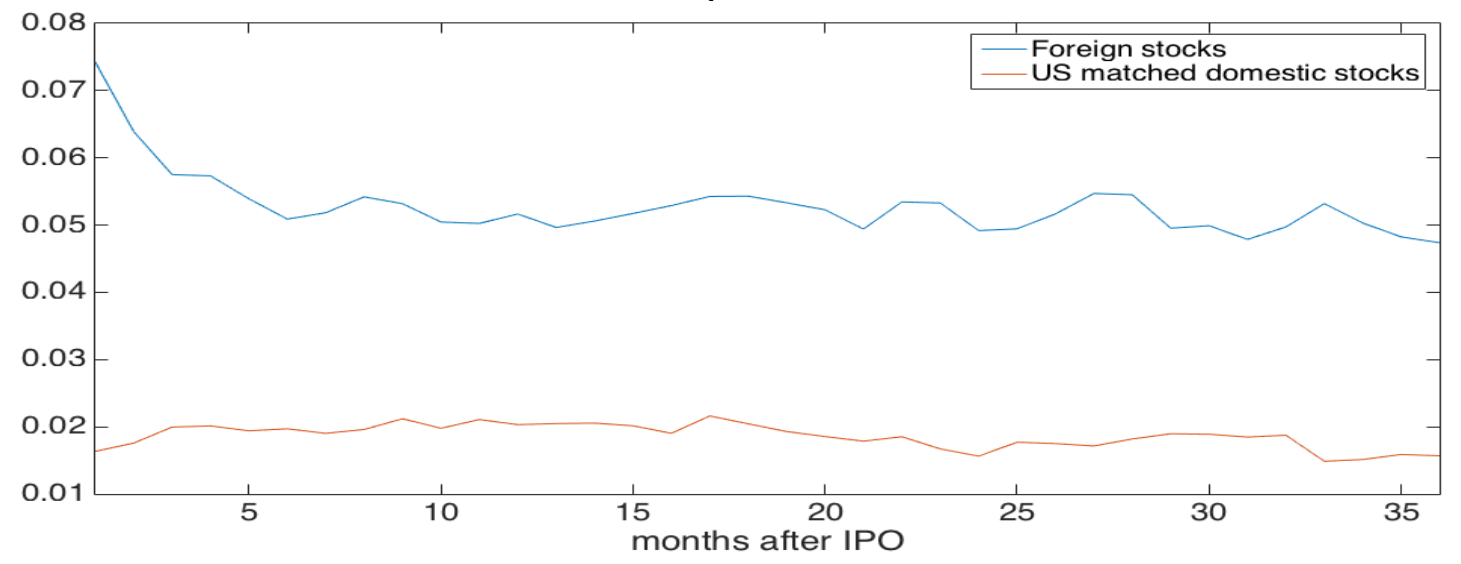

Notes: Liquidity levels of shares for foreign and matching domestic IPOs at monthly horizons after listing are plotted in Panel A. Liquidity is estimated as the Amihud ratio with opposite sign and multiplied by $10^{6}$. In Panel A the matching domestic measures are an order of magnitude smaller on average, so they are plotted against a secondary axis for more clarity. Panel B reports the percentage bid-ask spreads for foreign and matching domestic IPOs at monthly horizons after listing. 